\title{
What is the worth of values in guiding residential preferences and choices?
}

\author{
Sylvia J. T. Jansen
}

Received: 4 November 2010/Accepted: 8 February 2012/Published online: 24 February 2012

(C) The Author(s) 2012. This article is published with open access at Springerlink.com

\begin{abstract}
The demographic, socio-economic and socio-cultural shifts that have taken place in Western economies in recent decades have generated a broader variety in housing behavior. For this reason, some researchers argue that socio-demographic characteristics alone no longer suffice to predict the housing demand. They should be supplemented with 'lifestyle' variables. However, the worth of lifestyle for the prediction of the housing demand is a highly debated topic. The purpose of the current study, therefore, is to explore the worth of lifestyle (operationalized as values) in the prediction of residential preferences and choices. Data were collected through telephone interviews in January and February 2010. Respondents were asked to indicate the importance of 29 values as a guiding principle in housing. Furthermore, respondents who had indicated that they were willing to move $(\mathrm{n}=930)$ were asked about their preferences for a number of dwelling characteristics, such as tenure and dwelling type. Respondents who had indicated that they were not willing to move $(n=667)$ provided their residential choices. Hierarchical logistic regression analyses were used to explore the relationship between values and residential preferences and choices, after correction for socio-demographic characteristics. The results showed that values might have some additional worth for predicting residential preferences and choices, but the relationship seems to be rather limited.
\end{abstract}

Keywords Values - Lifestyle $\cdot$ Residential preferences $\cdot$ Residential choices $\cdot$ Housing

\section{Introduction}

Traditionally, housing demand is predicted from socio-demographic characteristics, such as age, education and income (van Diepen and Arnoldus 2003). It is assumed that social background may both create opportunities and limit choices (Ganzeboom 1988). For example, the birth of the first child-thus, the transition from couple to family-is 
frequently preceded or followed closely in time by a move from renting to owning (Clark et al. 1994). Bell (1958) argues that the move to the suburbs that he observed in families with children can be explained as an effort to find a place for family life that is more suitable than that offered by central cities.

However, people with the same background variables may have totally different preferences and behavioral patterns whereas people who score differently on the same background variables can have similar preferences (Michelson and Reed 1974; Wells 1974; Gunter and Furnham 1992; Pinkster and van Kempen 2002). Furthermore, demographic, socio-economic and socio-cultural shifts have taken place in Western economies in recent decades: households have become smaller and the variation in household types has increased. Other changes concern a greater variety of specific lifestyle-based subcultures and the increase in the proportion of affluent households. These shifts have generated a broader variety in housing behavior (van Diepen and Arnoldus 2003; Kersloot and Kauko 2004). This implies that the volume and quality of housing required will change as well as the locations at which that demand is expressed.

Based on this trend, some researchers suggest that traditional socio-demographic characteristics no longer suffice to explain and predict preferences for the built environment and for developing local government policy in the area of housing. Therefore, other ways are sought to predict the quantitative as well as the qualitative housing demand. One of these approaches is to add lifestyle variables to the traditional characteristics in the hope that it will lead to more accurate explanations and predictions of residential preferences and choices. In marketing, it has become rather common to use lifestyle variables as a supplement to socio-demographic characteristics in the prediction of preferences (Hustad and Pessemier 1974; Michelson and Reed 1974). Currently, a number of commercial research bureaus in the Netherlands are using the lifestyle approach for the prediction of the qualitative housing demand (see, for example, Hagen 2001; Nijhuis and Schoemaker 2002; Hessing and Reuling 2003). Usually, this concerns relatively small development projects in specified locations but lifestyle is also used on a larger scale (see, for example, the SmartAgent Company 2005). Nevertheless, the added worth of lifestyle is a subject of debate within the field of housing. Some arguments against the use of lifestyle are the following: (a) there is no consensus in the research field about what is meant by lifestyle (no definitional consensus); (b) lifestyles may not be stable but change quickly over time; (c) the relationship between lifestyle and residential preferences and choices has not been confirmed quantitatively; (d) there is a multitude of different lifestyle typologies; and (e) information on the psychometric properties of developed lifestyle typologies is often not provided. For a more elaborate discussion on this topic in the field of housing, the reader is referred to the following sources: Ganzeboom (1988); Nio (2002); Pinkster and van Kempen (2002); van Diepen and Arnoldus (2003); Heijs, Carton, Smeets and van Gemert (2005, 2009); Jansen (2011); and Heijs et al. (2011). Note that the discussion regarding the worth of lifestyle also takes place outside the domain of housing; see, for example, Michelson and Reed (1974), Anderson and Golden (1984), Lastovicka et al. (1990), Gunter and Furnham (1992) and Wedel and Kamakura (2000).

Lifestyle has been an area of interest to scholars in numerous disciplines, such as sociology, cultural anthropology, psychology, philosophy, marketing and human geography. As a result, definitions of lifestyle differ between disciplines. Furthermore, the definition of lifestyle also differs within disciplines. The concept of lifestyle may vary from a limited characteristic to a broad spectrum of behavior and various psychological and social variables. Despite the differences between the many definitions of lifestyle, most definitions agree that the purpose of lifestyle is to provide a context within which the behavior 
[or preferences] of one or more actors can be understood, especially in terms of the stability, coherence, and purposefulness of action (Michelson and Reed 1974). Thus, the search is for certain consistent patterns in lifestyle variables, such as activities, values or opinions, which differ between groups of consumers and that can explain and predict residential preferences and choices. A detailed discussion on the definition and operationalization of lifestyle is beyond the scope of this paper. More information on the concept of lifestyle is provided elsewhere: for example, Michelson and Reed (1974), Wells (1974), Zablocki and Kanter (1976), Anderson and Golden (1984), Ganzeboom (1988), Vyncke (2002), Pinkster and van Kempen (2002), van Diepen and Arnoldus (2003), Kipnis (2004), Heijs et al. (2005, 2009), and Jansen (2011). A short overview of the history of lifestyle in the field of housing is provided below.

Wirth (1938) developed a theoretical model for exploring urbanism as a way of life. He argued that features of cities such as large numbers, high density and ethnic heterogeneity were related to the relative absence of intimate personal acquaintanceships, to anonymous, superficial and transient relationships, and to increased mobility and insecurity. Merton (1957) introduced the terms cosmopolitans and locals. Residents who are oriented to the world outside the local community were classified as cosmopolitans whereas those oriented towards the community were termed locals. Bell (1958) made a distinction between Familism (a high value on family living), Career (upward vertical mobility) and Consumership (striving for a high standard of living in the present). He observed that child and family orientations rather than career considerations were the prime motives for respondents with a middle-class status to move to the suburbs (described in Tallman and Morgner 1970). Furthermore, households with a lifestyle that is directed to making a career can usually be found in close proximity to urban facilities, as these households want to spend their spare time as efficiently as possible.

In marketing, the lifestyle concept was introduced in the fifties to understand, explain and predict consumer behavior in order to focus marketing strategies (Anderson and Golden 1984). In 1963, Lazer introduced a concept of lifestyle that was based on three components: activities, interests and opinions (in Wedel and Kamakura 2000). Starting in the 1960s numerous lifestyle typologies were developed, as every product could have its own lifestyle typology. Typically, studies included up to 200 or 300 different items on activities, interests and opinions. A data reduction technique, such as factor analysis, would then be used to obtain a smaller number of psychographic dimensions (Wedel and Kamakura 2000).

Some examples of research that has developed or described lifestyle typologies in the field of housing are the following: Gans (1968), van Engelsdorp-Gastelaars (1980), Driessen and Beereboom (1983), Haest (1989), Ganzeboom (1990), Bastiaansen (1997), Reijndorp et al. (1998), Urhahn Urban Design (1999), De Wijs-Mulkens (1999), Kolpron Consultants and MarketResponse (2000), van Diepen and Musterd (2001), De WijsMulkens and Ostendorf (2001), Nijhuis and Schoemaker (2002), van der Schaaf (2002), Hessing and Reuling (2003), Overboom (2003), Hagen (2006), van Diepen and Musterd (2009), and Heijs et al. (2011).

The use of lifestyle in the field of housing shows some divergence. On the one hand, its use to predict the quantitative as well as the qualitative housing demand is a highly debated topic. On the other hand, lifestyle typologies flourish and are regularly used in urban planning or the production of housing. As van der Wouden and Kullberg (2002) argue, there is a big gap between the academic world of theoretical debate and methodological doubt, on the one hand, and the quick and uncritical development of lifestyle typologies by commercial bureaus, on the other. The purpose of the current study, therefore, is to explore 
the worth of lifestyle in the prediction of residential preferences and choices. More specifically, the research question is: To what extent can values predict residential preferences and choices, after correction for the impact of socio-demographic characteristics? The choice for the operationalization of lifestyle in the form of values is explained in the Methods section. A correction for socio-demographic characteristics is made to ensure that the relationships are not due to differences in the socio-demographic characteristics of the groups.

\section{Methods}

\subsection{The fieldwork}

The data used in this paper were collected in the context of a large study, "House Buyers in Profile", that has been performed every 1 or 2 years in the Netherlands since 1995 . This study gathers data on residential preferences and choices from respondents whose income is average or above, which applies to approximately $70 \%$ of all Dutch households. This criterion increases the probability that respondents actually have a choice with regard to carrying out their residential preferences. The goal of the "House Buyers in Profile" study is to determine the needs and wishes of future homebuyers in order to determine what has to be built. The data for the current study were collected through telephone interviews with about 2,000 respondents at the beginning of 2010 .

\subsection{Residential preferences and choices}

An important question during the telephone interview was whether respondents would be willing to move if they could find a dwelling that would fulfill all their housing needs. Respondents who said they were willing to move in such a situation were asked to indicate their preferences on a large number of dwelling characteristics. Respondents who were not willing to move were asked to provide information on their current dwelling characteristics, reflecting residential choices. The following characteristics are used in the current study: tenure (owner-occupied vs. rental); type of dwelling (single-family vs. multi-family); type of architectural design (traditional vs. modern/experimental); type of neighborhood (quiet vs. lively); and type of residential environment (inside the city vs. outside the city). The analyses are performed separately for each group.

\subsection{Values as operationalization of lifestyle}

Lifestyle can be operationalized in various ways, such as activities, opinions, interests and attitudes. The most frequently occurring operationalizations of lifestyle are based on the following: (1) behavior only (for example, buying behavior); (2) latent variables only (for example, attitudes, opinions); (3) a mix of behavioral and latent variables; (4) a combination of socio-demographic characteristics; and (5) a combination of socio-demographic characteristics and other variables. For the current study, it was decided to operationalize lifestyle on the basis of latent variables only. Thus, lifestyle is defined here as the orientation of people towards spending their time and money (Bootsma 1995). Behavioral variables were thought to be less useful in the prediction of residential preferences and choices. It is, for example, quite difficult to find behavior that would be related to the preference for a traditional architectural design. Besides, certain behavior can follow from 
very different motivations and does not necessarily reflect underlying preferences. Furthermore, socio-demographic characteristics are not believed to be part of lifestyle. A combination of socio-demographic characteristics may indicate a stage of the lifecycle or lifecourse but not lifestyle. As Pinkster and van Kempen (2002) argue, lifestyle is considered to be precisely that which cannot be explained by socio-demographic characteristics.

In the current study, lifestyle is operationalized in the form of values. These are deemed to play an important role in people's behavior in general and specifically in their preferences and choices (Coolen et al. 2002). Schwartz (2006) outlines the scope of basic values in the following terms: (1) values are beliefs that are linked to affect; (2) values refer to desirable goals that motivate action; (3) values transcend specific actions and situations (this means that they have a general impact and do not apply only to specific situations); (4) values serve as standards or criteria that guide the selection or evaluation of actions, policies, people and events; (5) values are ordered by importance relative to one another to form a system of priorities; and (6) the relative importance of values guides action, which means that the tradeoff among relevant, competing values is what guides attitudes and behaviors. Kersloot and Kauko (2004) argue that the choice of the dwelling can be understood as part of the person's general value orientation. Consumers are usually goaloriented and choose a particular dwelling because they pursue values and goals that are important to them. For example, one consumer might choose an apartment out of a desire for privacy (the value "privacy") because passers-by on the street cannot look through the windows. Yet another person might choose it because it is located in the city center and close to places of entertainment that stimulate an exciting life (the value "an exciting life"). Some well-known instruments for measuring values and value systems are the Rokeach Value Survey (Rokeach 1973), the List of Values (LOV, Kahle 1983) and the Schwartz Value Survey (Schwartz 1992).

The decision to operationalize lifestyle in terms of values was based on a number of arguments. First, as argued above, values might guide residential preferences and choices. Secondly, some researchers argue that values, as the innermost drivers of behavior, are more stable and generalizable than other lifestyle variables, such as activities and attitudes (Wedel and Kamakura 2000). Thirdly, values could be derived from a well-known and well-validated set, the Schwartz Value Survey (see, for example, Schwartz 1992 and Schwartz and Boehnke 2004). Finally, values are relatively easy to apply in a telephone survey.

The values applied in the present study were selected from the Schwartz Value Survey (1992). We rephrased some of them slightly in order to make them more appropriate for the field of housing. For example, we adapted Schwartz's original value "world peace" into "a dwelling environment at peace". We did this because, although we do expect values to guide behavior with regard to housing, we expect housing-specific values to have an even stronger relationship with residential preferences and choices. Furthermore, it makes it easier for the respondents to determine the importance of values as a guiding principle in housing. In accordance with Schwartz (1992), each item was followed in parentheses by a short phrase that further specifies its meaning, e.g., "Family security (safety for loved ones)".

We pretested the 56 adapted values in an expert sample, consisting of 15 colleagues (all of them researchers in the field of housing). We asked them to indicate the perceived importance of the values with regard to housing on a seven-point scale ranging from "not important at all" to "extremely important". On the basis of this pretest, we selected the 29 most important values for inclusion in the final list. We had to make a selection of values 
because these questions were part of a larger survey, as explained above. If too many questions were included, the interview burden for the respondents would be too high (fatigue, boredom, no more time, and so on).

The questions were phrased in the following way: "How important do you find [the specific value] as a guiding principle in housing?" (adapted from Schwarz's wording: "How important do you find [the specific value] as a guiding principle in life?"). The respondents could provide an answer on a seven-point scale ranging from "not important at all" (1) to "extremely important" (7).

Finally, it is important to note that the current study uses values in an explorative way to determine if there are any relationships with residential preferences and choices. The values are not assumed to divide the respondents into distinct lifestyle groups. This type of variable is called a lifestyle indicator by Heijs et al. (2011). In contrast, many lifestyle typologies set strict boundaries between various lifestyle groups. These groups are determined on the basis of shared lifestyle variables and are assumed to have similar (residential) preferences. A drawback of the latter approach is that important information can get lost by forcing respondents into specific groups that consist of combinations of variables (Heijs et al. 2005). Furthermore, people seldom belong to just one lifestyle group but show characteristics of multiple groups. A forced attribution to just one lifestyle group might unduly simplify the picture of the respondents.

\section{Results}

A sample of Dutch residents with at least an average income was obtained from a marketing bureau. After sending an introductory letter, 4,982 potential respondents were approached to participate in the study. Of those potential respondents, 2,057 (41\%) agreed to cooperate and $1,199(24 \%)$ refused. The remainder could not be contacted within the interview schedule (no answer, busy, answering machine, disconnected, other; $\mathrm{n}=1,726 ; 35 \%)$. The respondents were stratified according to region (north, east, south and west) so that the final sample contained approximately $25 \%$ from each region. They were also stratified according to age category (up to 40 years $=30 \% ; 41-54=35 \% ; 55$ and older $=35 \%$ ). However, the final sample contained somewhat fewer young respondents than planned $(23 \%)$ because they more often refused to cooperate or could not be contacted. Furthermore, as explained earlier, respondents, who had been selected by the marketing bureau, had to have at least an average income. In practice, however, almost five percent of the respondents $(n=63)$ turned out to have a lower than average income. These respondents were nonetheless retained in the analyses. The questionnaire could only be answered by homeowners, tenants or their partners.

In response to the question of whether or not they would be willing to move if they could find a dwelling that would satisfy all their needs with regard to housing, 930 respondents (45\%) answered positively. Eleven hundred and seventeen respondents were not willing to move in such a case and ten respondents were unable to answer the question. Due to budget constraints, 450 respondents in this latter group were presented with a very short version of the survey, one without the questions on the importance of values, thereby leaving only 667 respondents in the 'unwilling' group.

\subsection{The socio-demographic characteristics}

The socio-demographic characteristics included in this study are age, education, gender, household type, paid work and income. An explorative examination showed that age and 
income were not linearly related to the dependent variables, i.e., the preferred and actual dwelling characteristics. For this reason, they were recoded into categories and included as categorical variables in the analyses. Age was recoded into three categories: (1) up to 40 years of age; (2) 41-64; and, (3) 65 and older. Education originally had five levels, but the levels "higher vocational education" and "university" were pooled in the analyses. Furthermore, the category "other education" $(\mathrm{n}=5)$ was excluded. The variable household type had four levels: (1) single; (2) couple without children living at home; (3) couple with children living at home; and (4) other. Finally, the variable income was recoded into three levels: (1) below average to 1.5 times the average income; (2) 1.5-2.5 times the average income; and (3) more than 2.5 times the average income. The average net income in 2010 was found to be $€ 1,495$.

\subsection{The residential preferences and choices}

The following dwelling characteristics were used as dependent variables in the regression analyses: (1) actual or preferred tenure; (2) actual or preferred type of architectural design; (3) actual or preferred type of dwelling; (4) actual or preferred type of neighborhood; and (5) actual or preferred type of residential environment.

Actual tenure was explored by asking respondents whether they inhabited a rental dwelling $(\mathrm{n}=115 ; 17 \%)$ or an owner-occupied dwelling $(\mathrm{n}=547 ; 83 \%)$. Preferred tenure was explored by asking respondents whether they would like to inhabit a rental dwelling $(\mathrm{n}=226$; $25 \%)$, an owner-occupied dwelling $(\mathrm{n}=533 ; 59 \%)$ or had no preference $(\mathrm{n}=141 ; 16 \%)$. Respondents without a clear preference for tenure were excluded from the analyses.

After a short explanation of the types of architectural design, respondents were asked whether they inhabited a dwelling with a traditional $(\mathrm{n}=531 ; 82 \%)$, a modern $(\mathrm{n}=94$; $15 \%)$ or an experimental design $(n=20 ; 3 \%)$. In order to prevent generating categories with too few cases, the modern and experimental groups were pooled. To determine the preferred architectural design, respondents were asked whether they preferred a dwelling with a traditional $(\mathrm{n}=466 ; 52 \%)$, a modern $(\mathrm{n}=172 ; 19 \%)$ or an experimental design $(\mathrm{n}=49 ; 5 \%)$ or had no preference $(\mathrm{n}=209 ; 23 \%)$. The respondents without a clear preference were omitted from the analysis. Again, the modern and experimental groups were pooled.

The actual type of dwelling was explored by asking respondents whether they lived in a multi-family dwelling $(\mathrm{n}=51 ; 8 \%)$ or in a single-family dwelling $(\mathrm{n}=613 ; 92 \%)$. The preferred type of dwelling was explored by eliciting respondents' preferences for each of nine different dwelling types. Next, respondents were asked to indicate the most preferred dwelling type of those that had been selected. These preferences were divided into singlefamily dwellings $(n=663 ; 75 \%)$ and multi-family dwellings $(218 ; 25 \%)$.

The actual type of neighborhood was explored by asking respondents whether they lived in a very quiet neighborhood $(\mathrm{n}=132 ; 20 \%)$, a quiet neighborhood $(\mathrm{n}=335 ; 50 \%)$, a lively neighborhood $(\mathrm{n}=165 ; 25 \%)$ or very lively neighborhood $(\mathrm{n}=31 ; 5 \%)$. Next, these groups were pooled into residents living in a quiet neighborhood and those living in a lively neighborhood. The preferred type of neighborhood was explored in the same way. Five hundred and ninety-two respondents $(67 \%)$ indicated that they wanted to live in a (very) quiet neighborhood and 289 respondents (33\%) that they preferred to live in a (very) lively neighborhood. Fourteen respondents did not prefer either type of neighborhood; they were omitted from the analyses.

Residential environment was explored by asking respondents whether they lived: (a) in the city center ( $\mathrm{n}=61 ; 9 \%)$; (b) at the city's edge ( $\mathrm{n}=224 ; 34 \%)$; (c) in the built-up area 
of a smaller municipality $(\mathrm{n}=300 ; 45 \%)$; or $(\mathrm{d})$ outside the built-up area $(\mathrm{n}=79 ; 12 \%)$. The groups were pooled to form two groups: those living inside the city ( $\mathrm{n}=285 ; 43 \%$ ) and those living outside the city $(\mathrm{n}=379 ; 57 \%)$. The preference for living inside or outside the city was obtained in the same way as described above. After pooling the groups, two groups remained: respondents who prefer to live inside the city $(\mathrm{n}=425$; $52 \%)$ and those who prefer to live outside the city $(\mathrm{n}=397 ; 48 \%)$.

\subsection{The relationship between socio-demographic characteristics and residential preferences and choices}

The goal of the present paper is to determine the worth of values in the prediction of residential preferences and choices, after correction for socio-demographic characteristics. For this reason, the relationship between socio-demographic characteristics and residential preferences and choices has to be established. First, this relationship is explored in a univariate way. Table 1 shows the frequency distributions of respondents according to their socio-demographic characteristics for each of the five actual dwelling characteristics. The Chi-square test is used to test whether there are differences in the frequency distributions between groups for each of these characteristics. The results show that there are a number of statistically significant relationships $(p<0.05)$. In fact, of the 30 comparisons between the groups (six socio-demographic characteristics * five actual dwelling characteristics), $16(53 \%)$ turn out to obtain statistical significance. Household type is the most important socio-demographic characteristic; it is related to four out of five actual dwelling characteristics.

In a similar way, Table 2 shows the frequency distributions of respondents according to their socio-demographic characteristics, for each of the five preferred dwelling characteristics. The results show statistically significant relationships $(p<0.05)$ for $17(57 \%)$ comparisons. Age, household type and paid work are each related to four out of five preferred dwelling characteristics.

After exploring the univariate relationships between socio-demographic characteristics and residential preferences and choices, the mutual effect of the socio-demographic characteristics is explored in logistic regression analyses. All analyses followed the same approach. A logistic regression was performed with the particular actual or preferred dwelling characteristic as dependent variable and the socio-demographic characteristics as predictors. The deviation contrast was selected as this provides insight into the performance of each category compared to the overall effect of the particular variable. Four model-building approaches were followed in order to obtain the best model, which was defined as the one with the highest percentage of correctly classified cases. In the final model, only the statistically significant predictors $(p<0.05)$ were included. The four approaches are as follows:

1. A model including only those socio-demographic characteristics that univariately were related to residential preferences and choices (see Tables 1 and 2). The method "enter" was used. Next, the characteristic with the highest, non-significant, $p$ value was omitted from the analysis. This process was repeated until only statistically significant predictors remained (backward-elimination-by-hand procedure).

2. All socio-demographic characteristics were entered simultaneously and a Forward procedure was used to determine the optimal set of predictors.

3. All socio-demographic characteristics were entered simultaneously and a Backward procedure was used to determine the optimal set of predictors. 


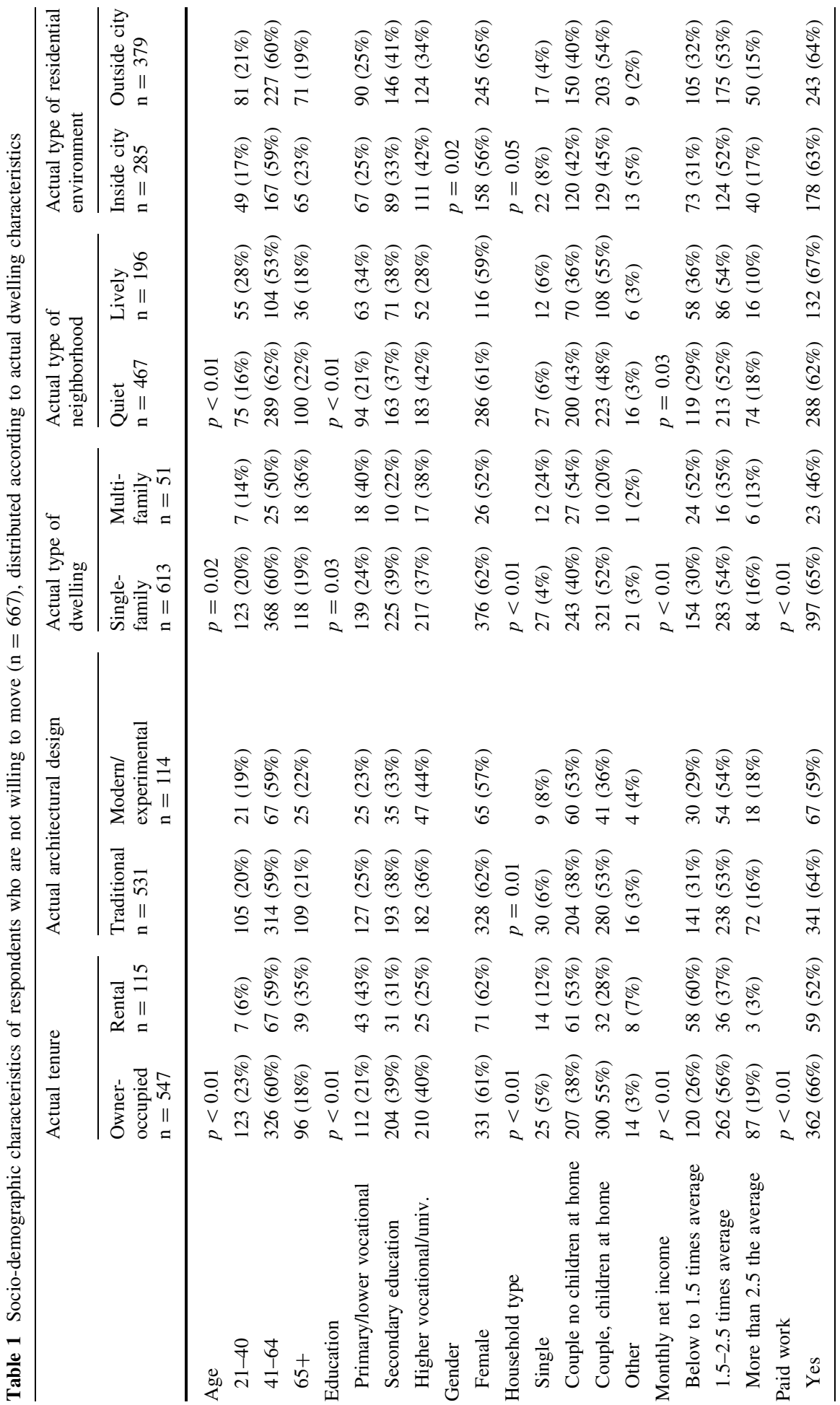




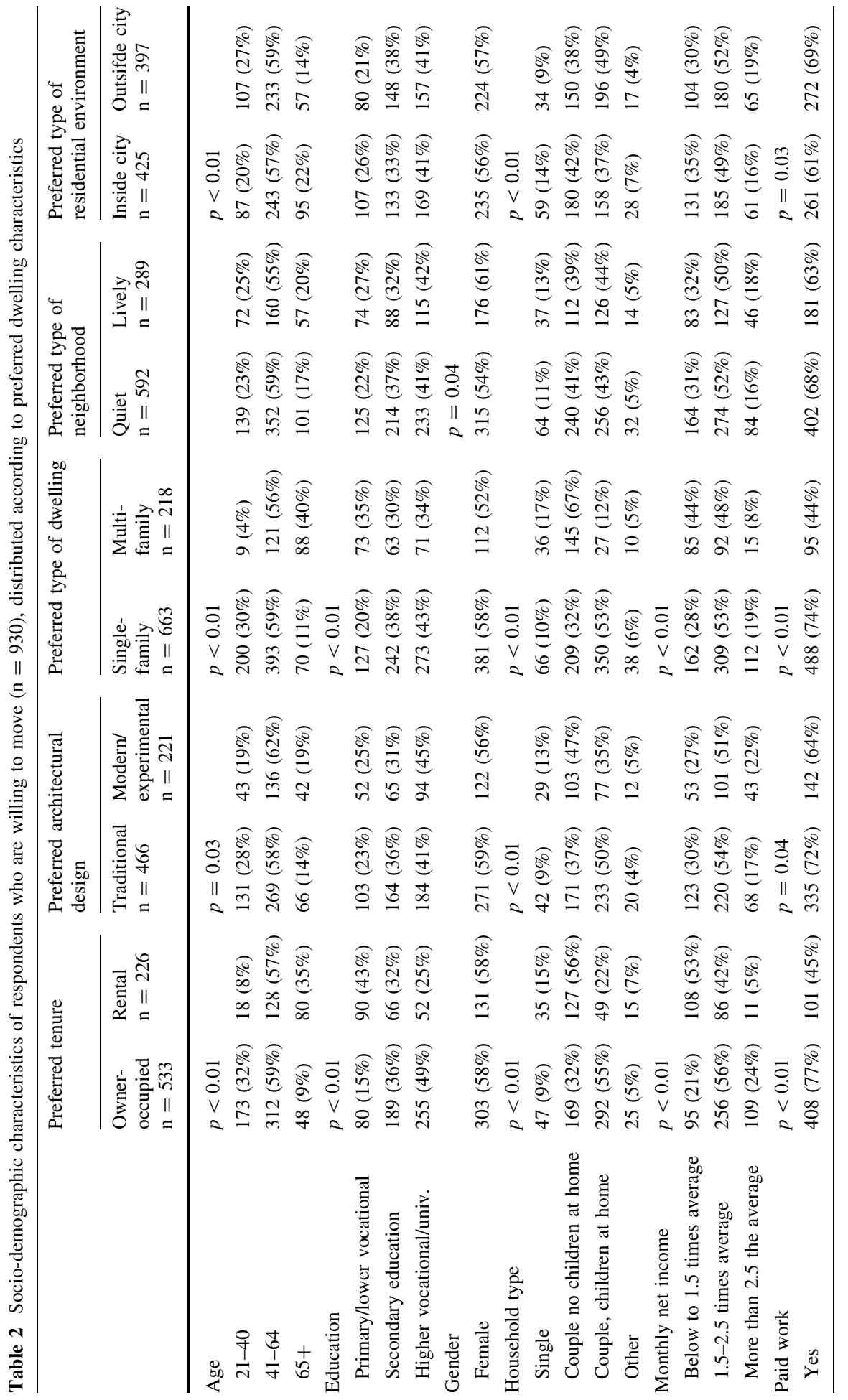


4. All socio-demographic characteristics were entered simultaneously and the method "enter" was used. Next, the predictors that multivariately showed a statistically significant relationship with the dependent variable were selected and included in the subsequent regression analysis. Next, the backward-elimination-by-hand procedure was followed as described under 1).

\subsection{Multivariate relationships between socio-demographic characteristics and residential preferences and choices}

The multivariate results for the relationships between socio-demographic characteristics and actual dwelling characteristics are shown in Table 3. Similarly, the results with regard to the residential preferences are shown in Table 4. The "constant only" model is the base model in the logistic regression; it attributes all cases to the group with the highest probability of group membership. The "socio-demographics" model shows the change in the percentage of correctly classified cases as a result of the inclusion of the statistically significant predictors. Nagelkerke $\mathrm{R}^{2}$ is a measure of fit; it provides a gauge of the substantive significance of the model (Field 2009). The odds ratio reflects the change in odds (which is the probability of the event occurring divided by the probability of the event not occurring) resulting from a unit change in the predictor (Field 2009). The 95\% confidence interval (CI) around the odds ratio reflects its accuracy. The confidence interval indicates that for $95 \%$ of the time the true odds ratio in the population will fall within these limits (Field 2009). Thus, if the confidence interval is large, then the result is less precise. If the confidence interval does not contain the value " 1 ", the predictor has a statistically significant impact on the dependent variable.

The results show that the value of Nagelkerke $\mathrm{R}^{2}$ for the influence of the sociodemographic characteristics alone ranges from 0.01 to 0.22 for the actual dwelling characteristics. The additional percentage of overall correctly classified cases, when compared to the base model (constant only), is only $1 \%$ at most. For residential preferences, the value of Nagelkerke $\mathrm{R}^{2}$ ranges between 0.01 and 0.41 : a $0-8 \%$ increase in the overall percentage of correctly classified cases.

Household type is the most important predictor of residential preferences and choices in this study. It has a statistically significant impact in seven out of ten analyses. Both age and income show a statistically significant relationship with one of the five actual dwelling characteristics and three of the five preferred dwelling characteristics.

Actual tenure can be predicted on the basis of education, household type and income. Household type is the only statistically significant predictor of actual architectural design and of actual dwelling type. Age and education are statistically significant predictors of actual type of neighborhood. Finally, gender is the only statistically significant predictor of actual type of residential environment.

Preferred tenure can be predicted on the basis of education, household type, age, income and having paid work. Household type and monthly net income show a statistically significant relationship with preferred architectural design. Household type, age and income are statistically significant predictors of preferred type of dwelling. Gender is the only socio-demographic characteristic that is related to preferred type of neighborhood. Finally, household type and age show a statistically significant relationship with preferred type of residential environment. 


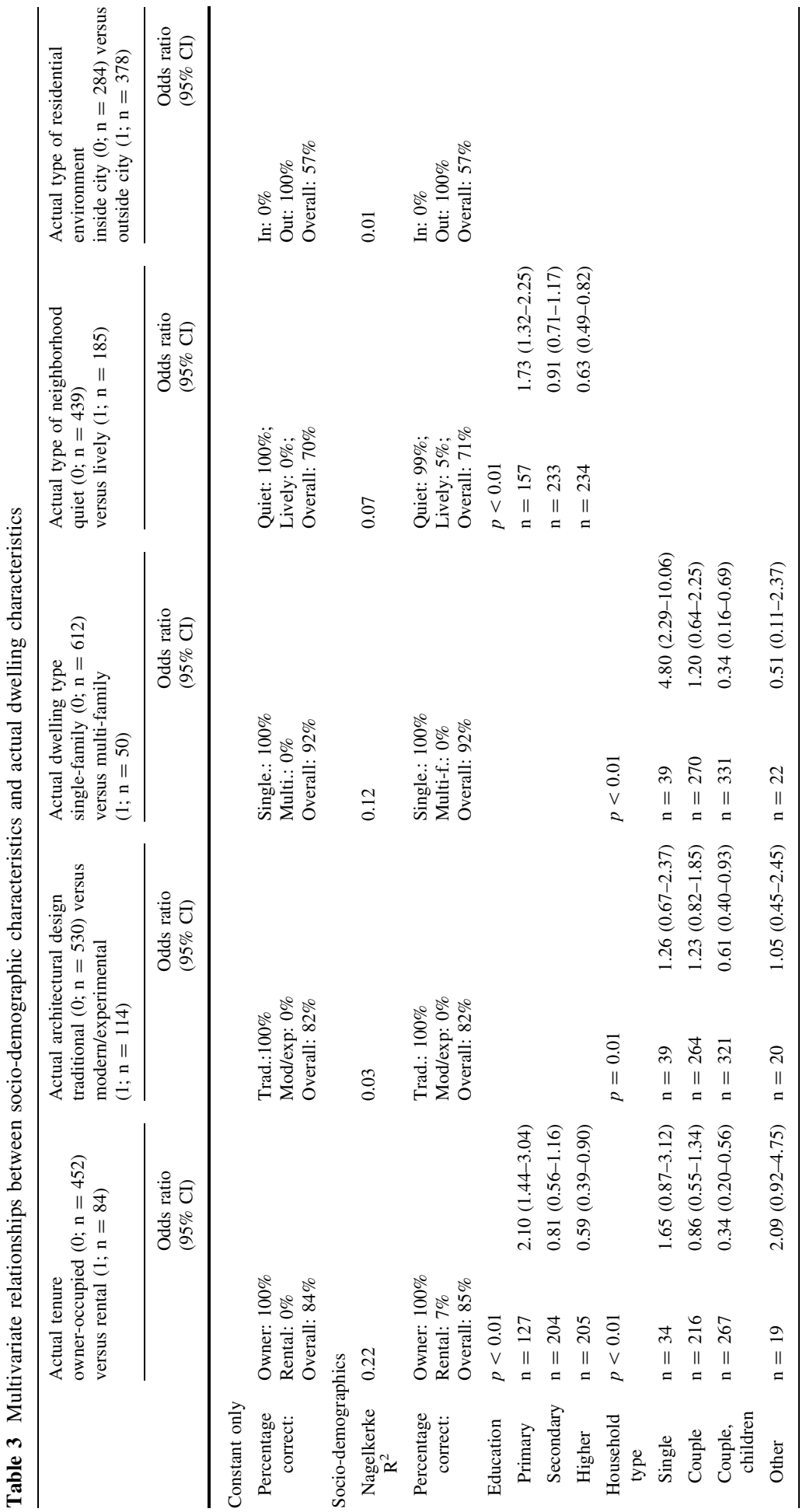




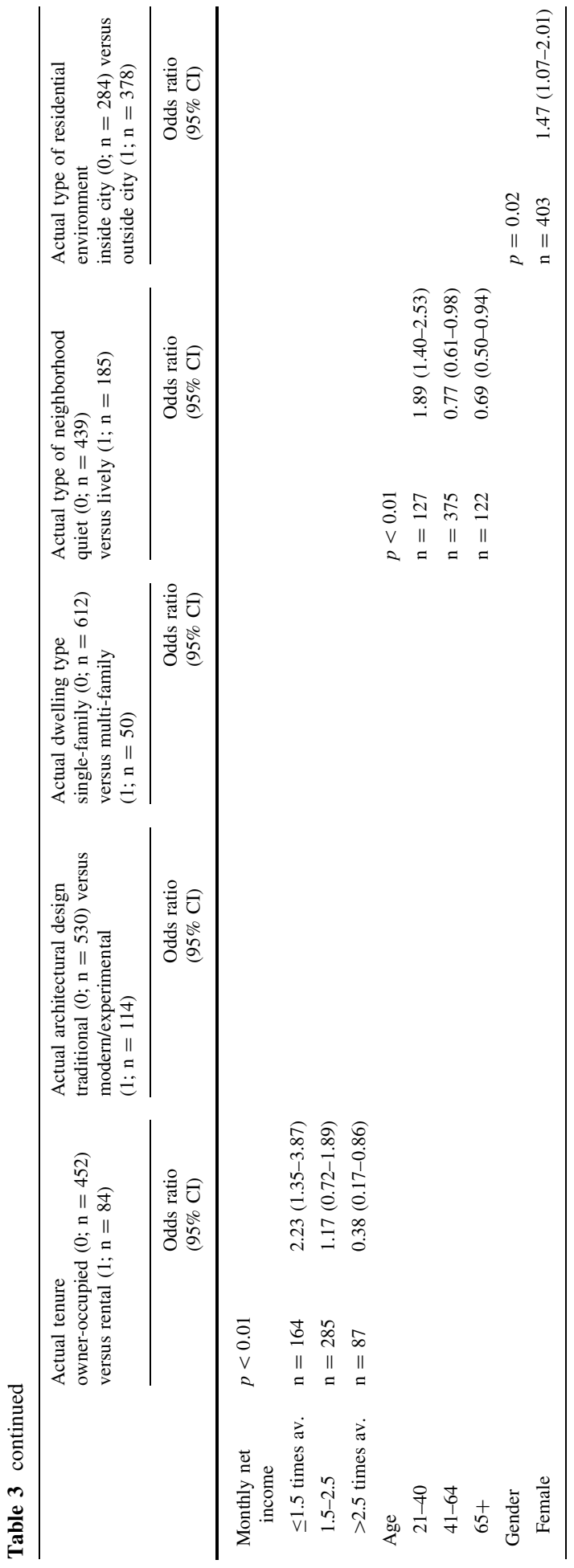




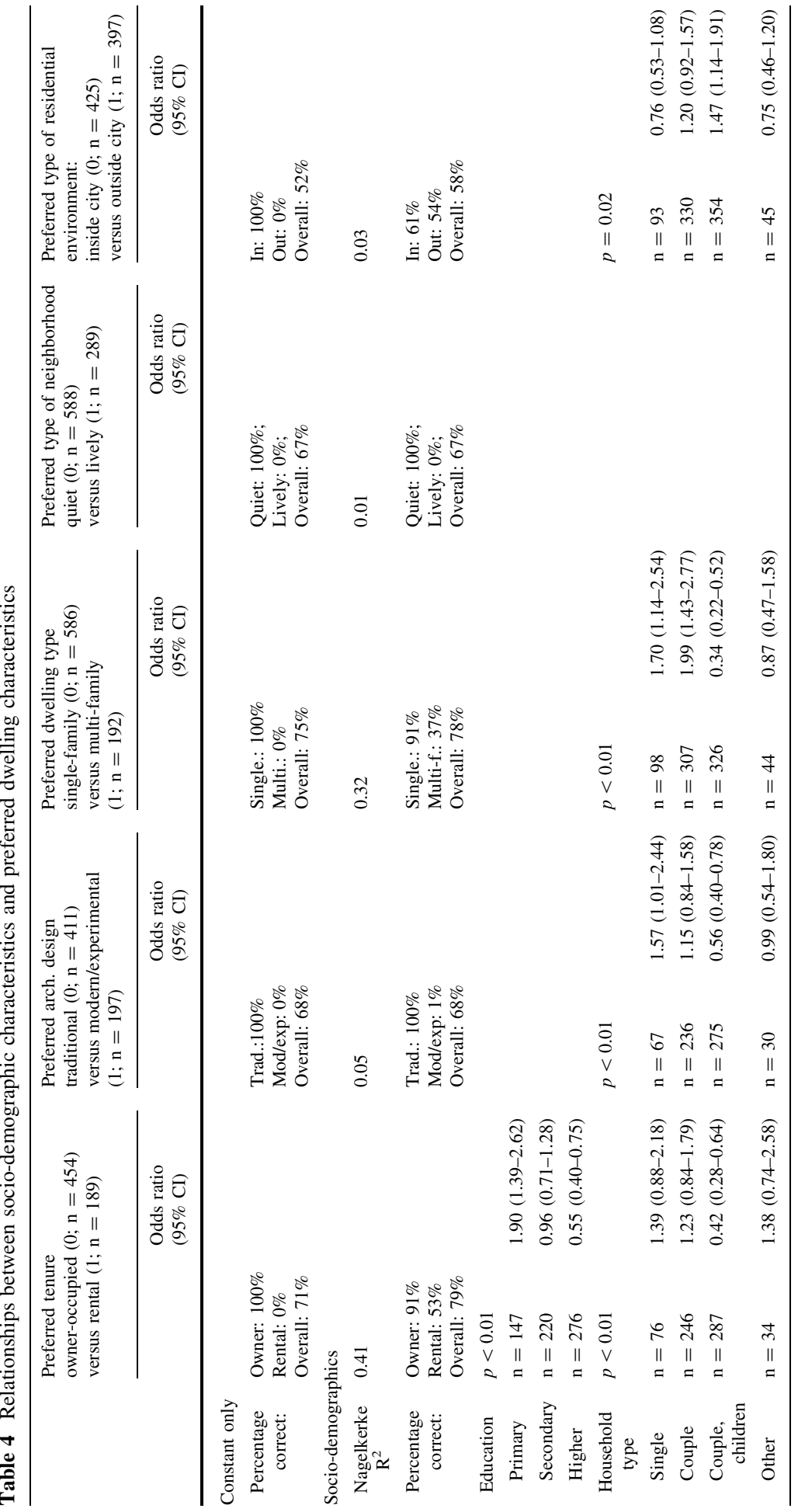




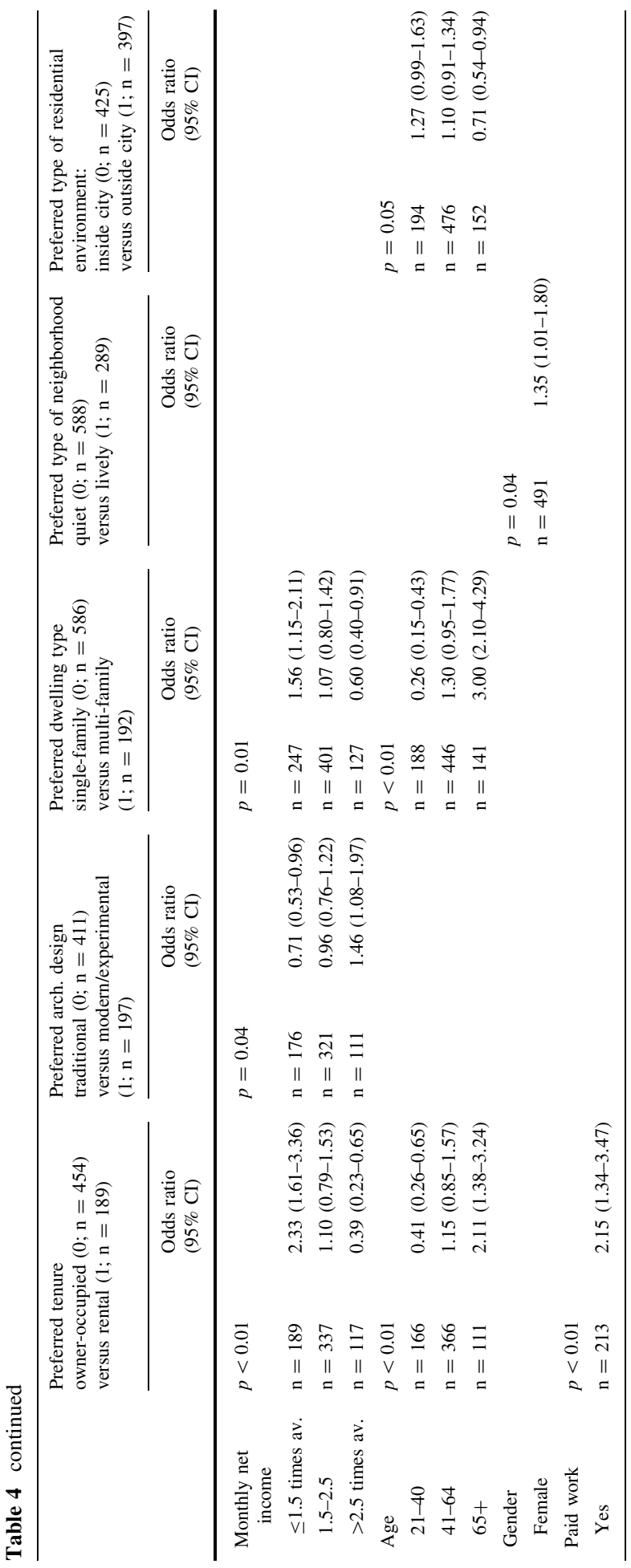




\subsection{The impact of values}

In the next set of analyses, the relationship between values and residential preferences and choices is explored. The values turned out to be highly skewed to the left and not linearly related to the (preferred) dwelling characteristics. For this reason, the original seven answering categories were recoded into two categories, one category with the values 1-4 (unimportant) and one category with the values 5-7 (important).

First, the univariate relationships between socio-demographic characteristics and values will be briefly summarized (results not shown). The Chi-square statistic is used to explore these relationships. The largest number of statistically significant relationships is found for education (for 17 out of 29 potential relationships). Generally, the higher the education, the less important the values are considered to be. For gender, nine relationships show a statistically significant result. Women believe the following values to be more important than men as a guiding principle in housing: "household order", "equality", "respect for tradition", "privacy", "wealth", "self-respect", "detachment", "social power" and "accepting my portion in life". Respondents without paid work find the following seven values more important than those who do have paid work: "social recognition", "preserving my public image", "unity with nature", "sense of belonging", "protecting the environment", "detachment" and "social power". Furthermore, they find "family safety" less important than respondents with paid work. Household type is related to six values. Couples without children living at home find "social recognition", "equality" and "unity with nature" more important. Singles find "household order" and "equality" less important. Finally, couples with children living at home find "preserving my public image" and "sense of belonging" less important than the other household types. Older respondents more frequently find "social recognition", "preserving my public image", "unity with nature", "respect for tradition" and "sense of belonging" important than younger respondents. Finally, respondents with lower incomes more frequently find "social recognition", "preserving my public image", "sense of belonging", "wealth" and "social power" important.

Next, the relationship between values and residential preferences and choices is explored. Table 5 shows the frequencies of respondents who find the particular value important, divided into groups according to their actual dwelling characteristics. The Chisquare test is used to examine whether there are differences between the groups of residents. The table shows that the largest number of statistically significant relationships ( 9 times out of 29) is found for actual tenure. The value "unity with nature" shows the highest number of relationships with actual dwelling characteristics (for three out of five).

Table 6 shows the results for the five preferred dwelling characteristics. Again, the largest number of statistically significant differences is found for tenure (10 times). There are a number of values that univariately show relationships with three out of five preferred dwelling characteristics: "preserving my public image", "social recognition", "sense of belonging", "protecting the environment" and "an exciting life".

Now the question arises whether the univariate relationships between values and residential preferences and choices are really the result of differences in the perceived importance of values, or that they are due to differences in socio-demographic characteristics between the groups. To answer this question, the relationship between each of the ten actual and preferred dwelling characteristics is explored, after correction for sociodemographic characteristics. In the first block of a hierarchical regression analysis, the optimal set of socio-demographic characteristics, as determined in the previous analyses, was included. For example, education, household type and income were included in the 


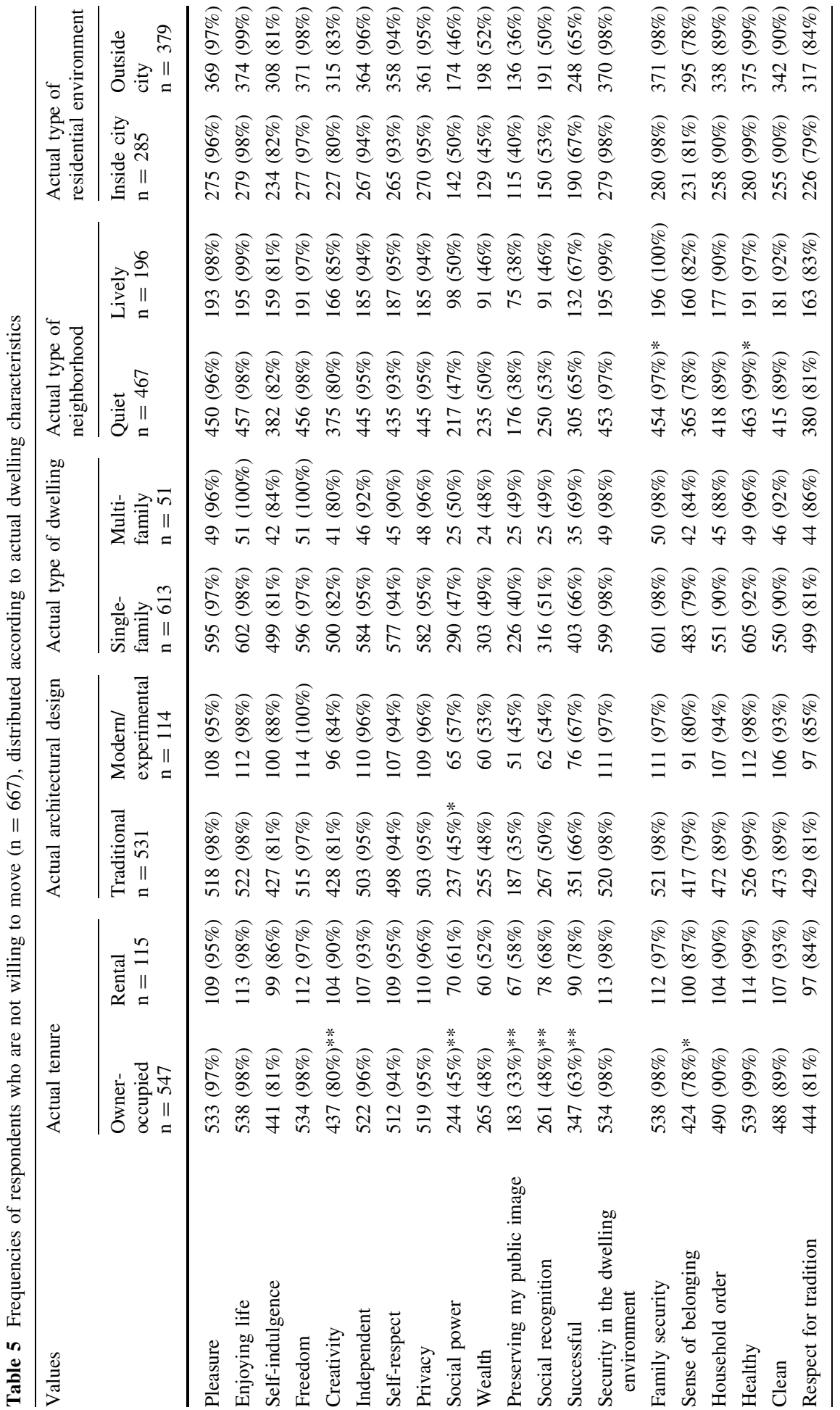




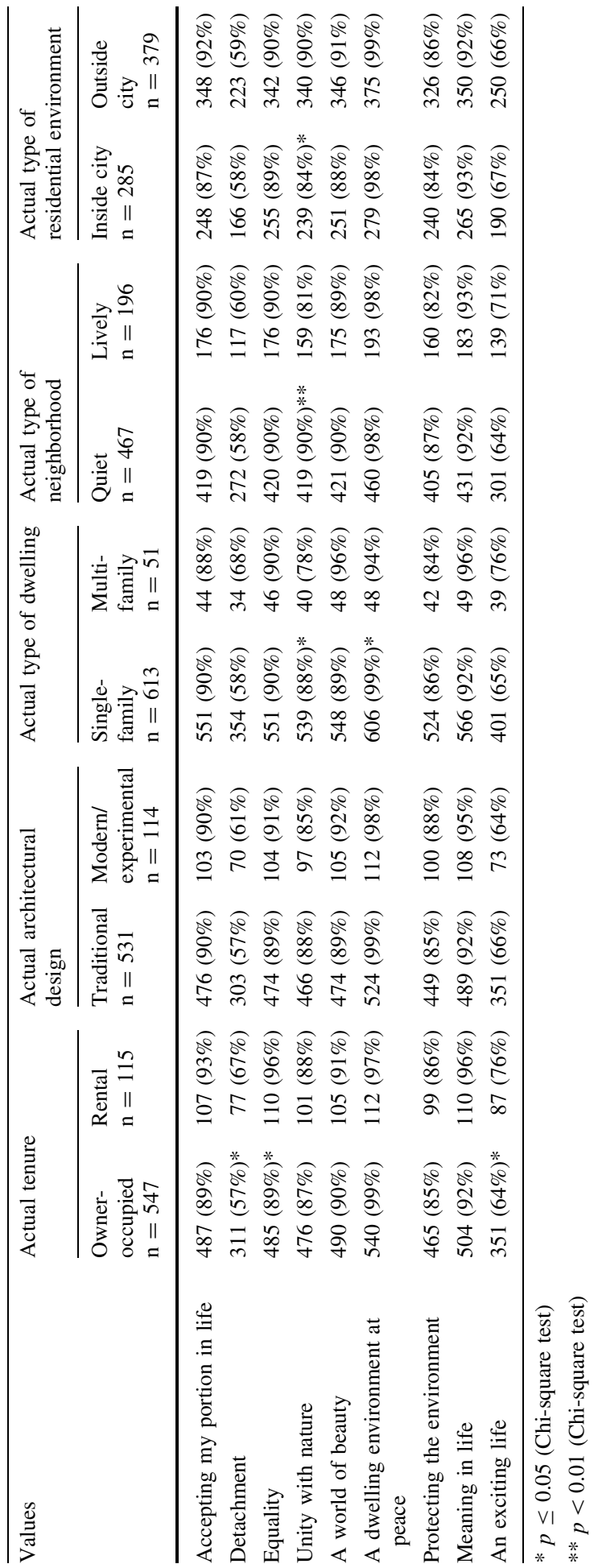




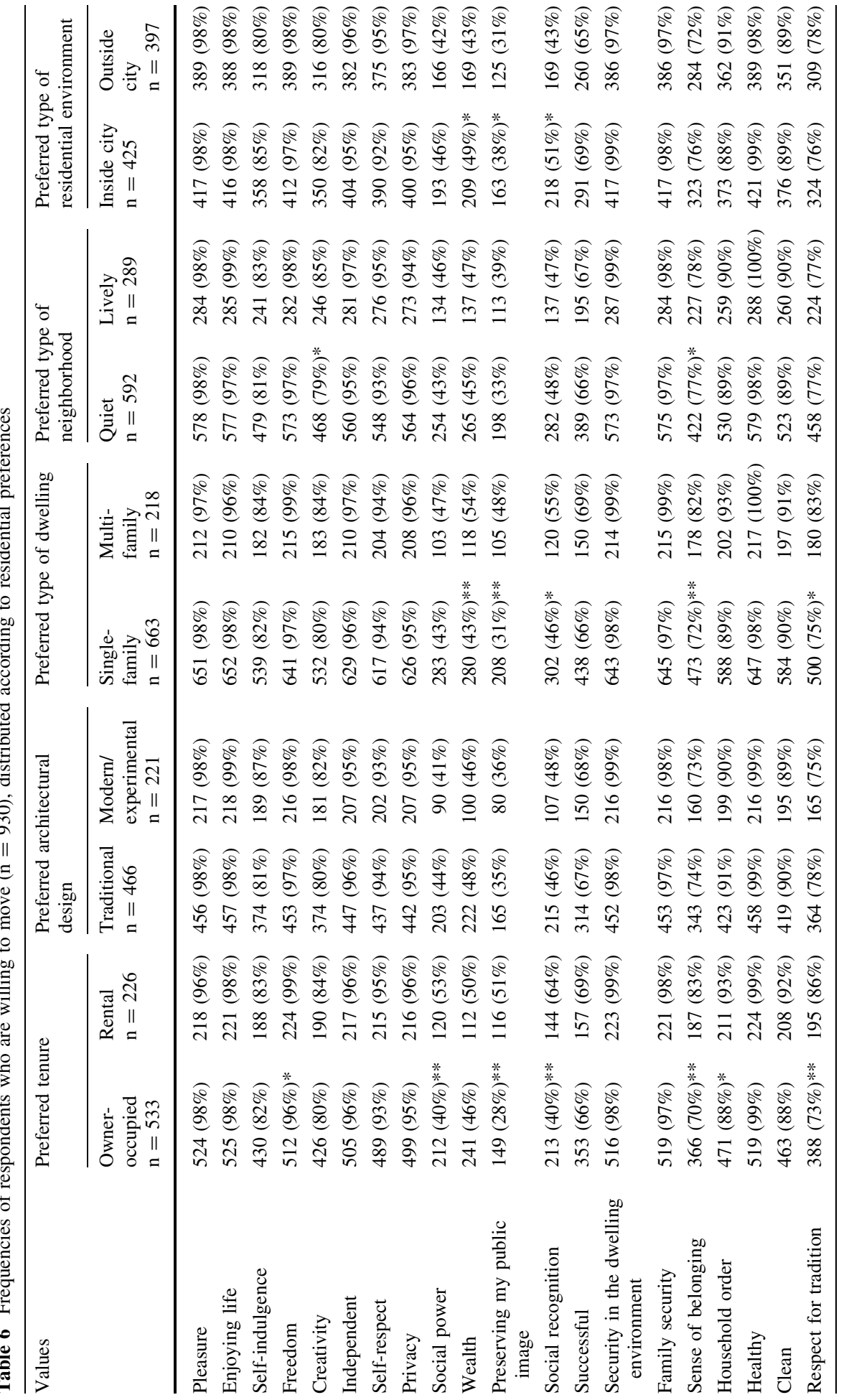




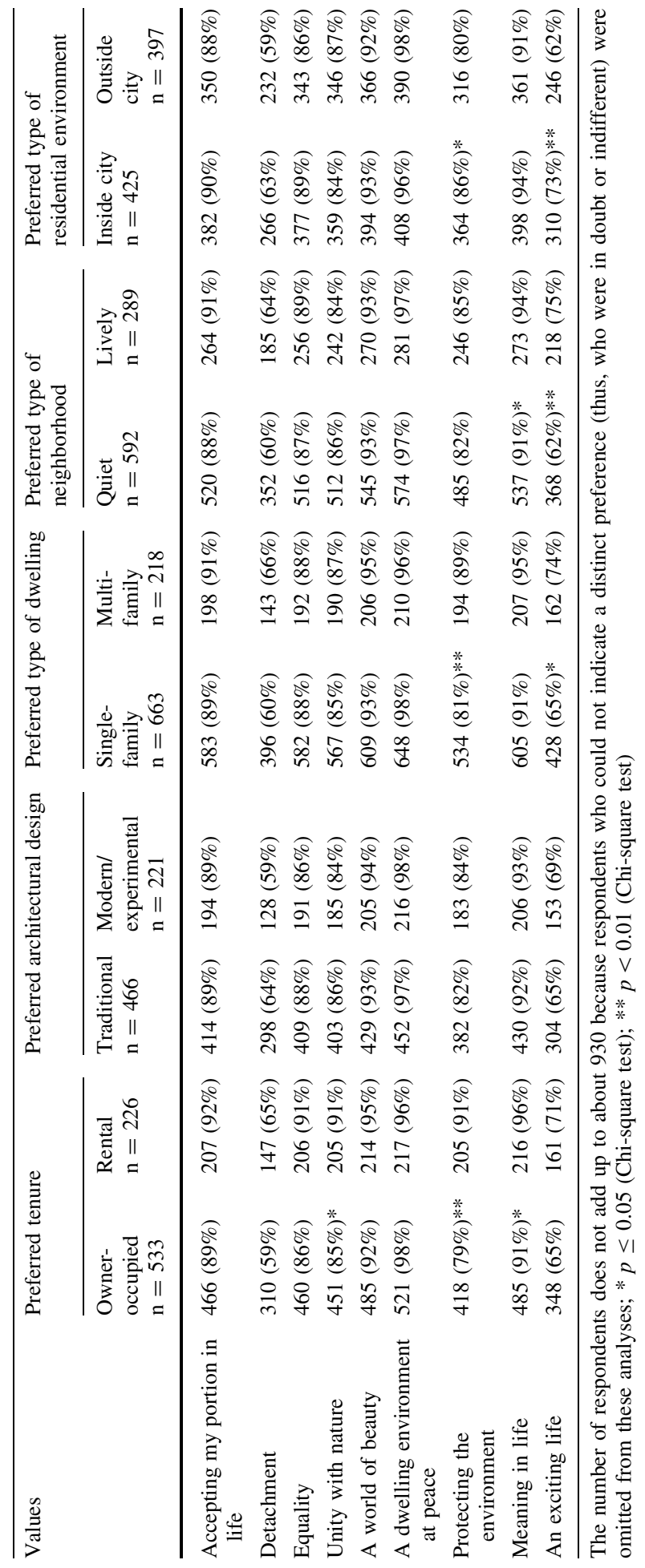


first block of the regression analysis for the prediction of actual tenure (see Table 3). Next, the values were included in the second block of the regression analysis. This ensured that the impact of the values was explored after correction for the impact of the socio-demographic characteristics. The simple contrast was selected for the values as this provides insight into the performance of the second category (important) compared to the first category (unimportant). The best model was determined using the same four procedures as described for the socio-demographic characteristics. Incidentally, a value turned out to yield unreliable results due to a lack of sufficient cases in the particular category. This problem is reflected in a wide $95 \%$ confidence interval. Whereas categories could not be pooled, the value was omitted in such a case, as it would lead to unreliable results that would apply to only a few respondents.

The results are presented in Table 7 (actual dwelling characteristics) and Table 8 (preferred dwelling characteristics). The "worth" of values in the prediction of residential preferences and choices can be determined by comparing the block with the values to the block with the socio-demographic characteristics, with regard to the percentage of correctly classified cases and the additional value of Nagelkerke $R^{2}$. The values increase the value of Nagelkerke $\mathrm{R}^{2}$ by $0.01-0.05$ in the prediction of actual dwelling characteristics: a $0-2 \%$ increase in the overall percentage of correctly classified cases. The increase in the value of Nagelkerke $\mathrm{R}^{2}$ in the prediction of the residential preferences ranges from 0.0 to 0.04 . The overall percentage of correctly classified cases increases by $0-2 \%$. Thus, after correction for socio-demographic variables, the impact of values on residential preferences and choices is quite small.

The value "an exciting life" has a statistically significant relationship with actual and preferred dwelling characteristics in six out of ten analyses. Respondents who find this value important are more likely: (a) to have a rental dwelling; (b) to have a multi-family dwelling; (c) to prefer a multi-family dwelling; (d) to live in a lively neighborhood; (e) to prefer a lively neighborhood; and, (f) to prefer to live inside the city. The value "a dwelling environment at peace" is a statistically significant predictor in three out of ten analyses. In all of these cases, it concerns preferences. Respondents who find "a dwelling environment at peace" important are about 3.6, 6.7 and 3.5 times more likely to prefer an owneroccupied home, a single-family home and to live outside the city, respectively. The value "unity with nature" is an important predictor in three out of ten analyses; all of these cases concern actual dwelling characteristics. Respondents who find "unity with nature" important are about 2.8, 2.1 and 1.7 times more likely to live in a single-family home, to live in a quiet neighborhood and to live outside the city, respectively. Finally, the value "social recognition" has a statistically significant impact in two out of ten analyses. Respondents who find "social recognition" important are 1.6 times more likely to live in a quiet neighborhood and are almost two times more likely to prefer a rental dwelling. All other statistically significant values have an effect on only one of the ten actual or preferred dwelling characteristics.

\section{Discussion}

The research question that is explored in the current study is the following: To what extent can values predict residential preferences and choices, after correction for the impact of socio-demographic characteristics? The results show that values have only a small impact on residential preferences and choices. These results agree with those of other published studies that explored the impact of values, or lifestyle groups based on other variables, on 


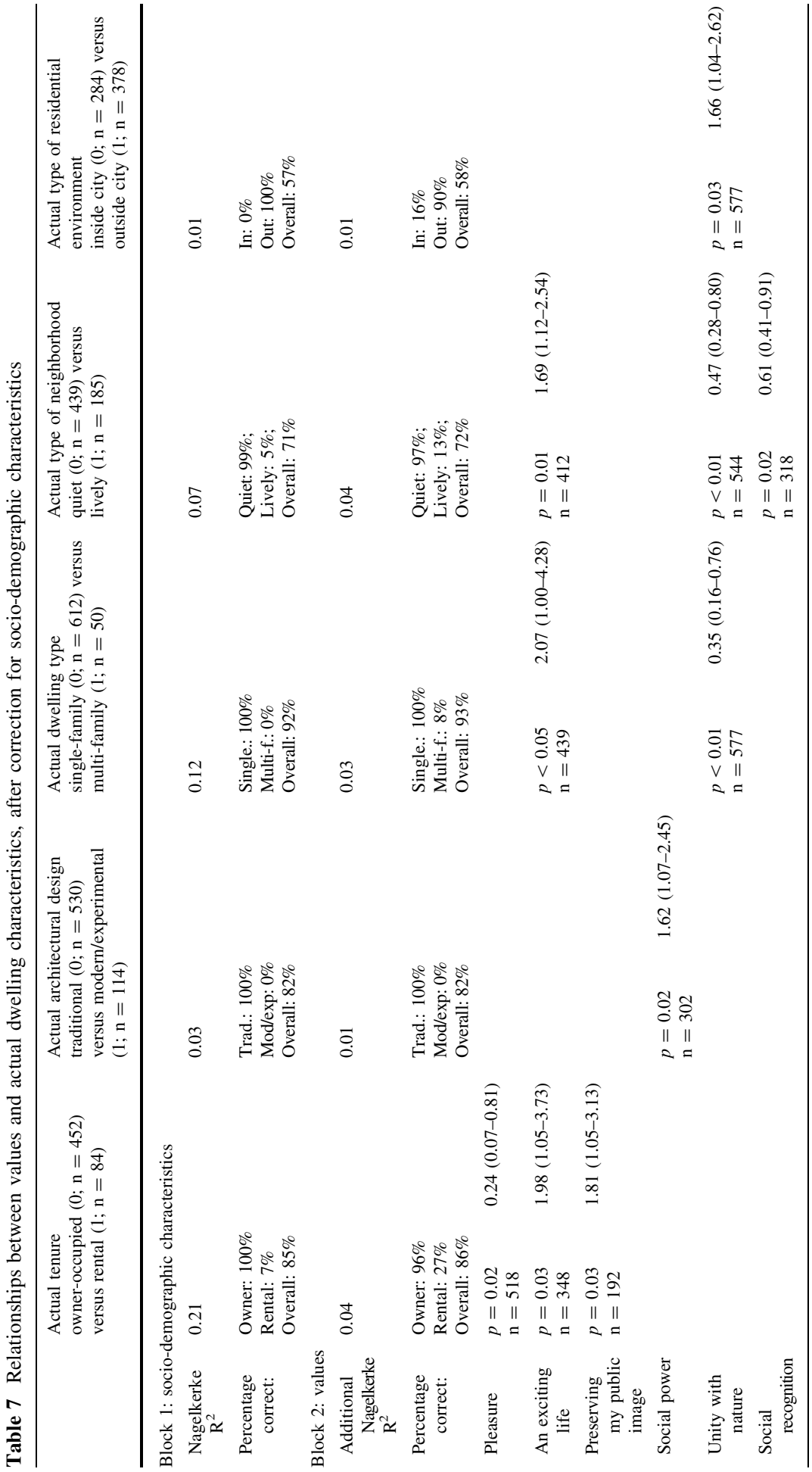




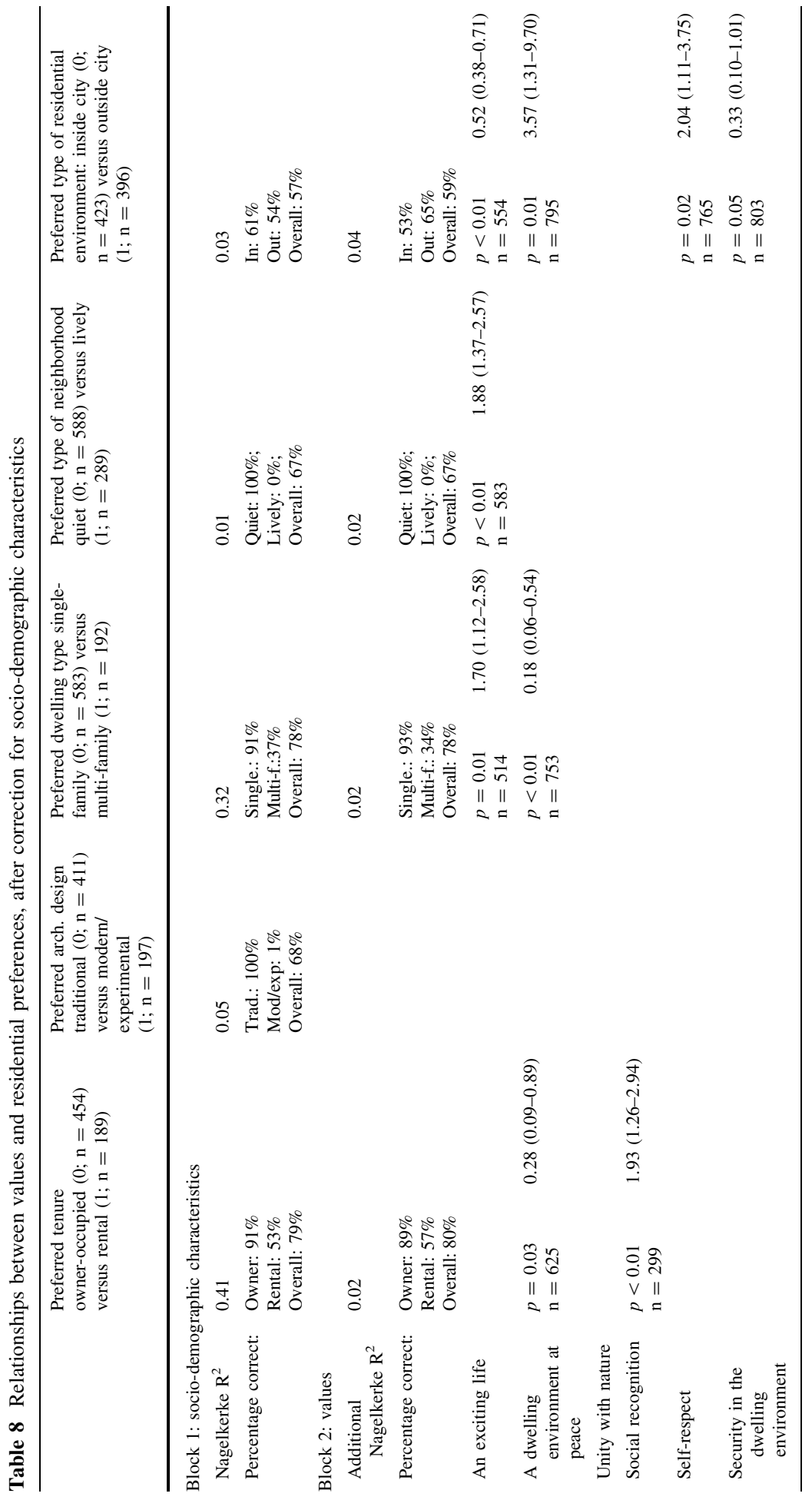


residential preferences in a quantitative way. Bootsma (1995) predicted the residential location choice (urban/suburban) of couples from socio-demographic characteristics and values regarding gender-role orientation and work orientation (lifestyle indicators). The results showed that gender-role orientation could not predict residential location choice but that work orientation could. Women, who consider paid labor important relative to raising children and doing household tasks, are more likely to live in cities. Coolen et al. (2002) explored the added worth of values (lifestyle indicators) in the relationship between intended tenure choice and socio-demographic characteristics. They showed that intended tenure choice could be predicted by age, current tenure, income and household composition (explained variance: 39\%) and that values have a small, but statistically significant, additional effect (explained variance: 4\%). The more important the values of power and achievement were deemed to be, the greater the tendency towards owning. Also, the more important family values were, the higher the tendency to rent. Driessen and Beereboom (1983) composed seven lifestyle groups on the basis of questions on recreational activities, such as doing sports, and activities with a more or less obligatory character (work-related). They explored whether these seven lifestyle groups differed in their preferences with regard to 21 aspects of the urban residential environment, such as a quiet neighborhood and the availability of a garden. The authors found differences between lifestyle groups for only three of the 21 aspects and concluded that the results using lifestyle groups were no better than the results based on lifecycle situation, social-economic position and housing location alone. Pinkster and van Kempen (2002) explored the relationship between socioeconomic and demographic variables, lifestyle variables (both behavioral and latent lifestyle indicators) and the preference for type of residential environment. They showed that household composition, age, income, education and ethnicity could predict the preferred type of residential environment. Furthermore, they found statistically significant relationships with lifestyle variables such as visiting museums, frequenting churches and being interested in politics. In all of these cases, the amount of explained variance of the logistic regressions was larger if lifestyle variables were included. However, the impact of lifestyle variables was much smaller than the impact of the socio-demographic characteristics. Finally, Heijs et al. (2011) explored whether lifestyle groups (based on behavioral intentions) could act as a supplement to traditional variables in the prediction of residential preferences. The authors concluded that a majority (84\%) of the residential preferences were not related to lifestyle groups. Furthermore, in the remaining cases the traditional variables (sometimes combined with basic sociocultural characteristics) could predict residential preferences as well as the lifestyle groups did.

There are other studies that explored the relationship between values and residential preferences and choices. However, these studies were not set up with the intention to explore the additional worth of values, after correction for socio-demographic characteristics. Examples of such studies are Lindberg et al. (1988, 1989, 1992), Coolen and Hoekstra (2001) and Lundgren and Lic (2010).

It is interesting to note that the current study as well as other studies (Coolen et al. 2002; Pinkster and van Kempen 2002; Heijs et al. 2011) show that socio-demographic characteristics still have a statistically significant relationship to residential preferences and choices. These results do not support the suggestion that socio-demographic characteristics no longer suffice to explain residential preferences because of the increased socio-cultural complexity of society, as mentioned in the Introduction section.

The observed relationships between values and residential preferences and choices generally do show face-validity. Respondents who find "an exciting life" important are more likely to live in a lively neighborhood, to prefer a lively neighborhood and to prefer to 
live inside the city. It is likely that the best place to find excitement would be situated in a lively neighborhood inside the city. Furthermore, these respondents are more likely to have a rental dwelling, to have a multi-family dwelling and to prefer a multi-family dwelling. The housing stock of cities consists largely of multi-family dwellings in the social rented sector (Bootsma 1995). In contrast, respondents who find "a dwelling environment at peace" important are more likely to live in a single-family dwelling and to prefer an owneroccupied house, a single-family dwelling and to live outside the city. Indeed, a logical place for a peaceful residential environment would be a single-family, owner-occupied dwelling located outside the city. Similarly, respondents who find "unity with nature" important are more likely to live in a single-family home, in a quiet neighborhood, and outside the city.

These results provide a slight indication that residents may indeed choose or prefer a particular dwelling because they pursue values and goals that are important to them. However, the results presented in the current paper cannot demonstrate a causal nature in the relationship between values and residential preferences and choices. It is, therefore, not clear whether values lead residents to choose particular dwelling characteristics or environments, or that residents adapt their values to their actual living circumstances or future prospects. A longitudinal study would be needed to be able to determine such a causal relationship. A similar diversity is also present in the literature. Van Diepen and Musterd (2009) make a distinction between scholars that consider lifestyle to be an effect of the characteristics of the urban environment. In this sense, they refer to Wirth (1938), Zukin (1998), Clarke (2003), Sobel (1981) and Bourdieu (1984). The other approach regards the urban-regional distribution of household types a result of household formation and behavioral practices (van Diepen and Musterd 2009). The authors consider Bell (1968) as a proponent of this latter approach.

The relationship between residential preferences and lifestyle is complicated. Housing includes many aspects: some are physical, such as the dwelling type and the number of rooms; others are locational or social, such as the number and distance of various facilities or the type of residents in the neighborhood. This might explain the limited impact of values on residential preferences and choices. As Prensky and Wright-Isak (1997) argue, attitudes and behaviors are enactments of values and enactment is a sociocultural process that occurs in the context of a community. Other factors that might preclude the transition from values into preferences and choices are the housing market situation, the values and preferences of other members of the household and work- and family-related concerns.

In the current paper, the value of Nagelkerke $\mathrm{R}^{2}$ is provided as a measure to determine the worth of values in predicting residential preferences and choices. The variance of a dichotomous or categorical dependent variable depends on the frequency distribution of that variable. This means that R-squared measures for logistic regressions with differing marginal distributions of their respective dependent variables cannot be compared directly. Therefore, the reported $\mathrm{R}^{2}$ measures have to be considered as approximations to Ordinary Least Squares $\mathrm{R}^{2}$, not as actual percentages of variance explained. However, as the current study only determines the additional value of Nagelkerke $\mathrm{R}^{2}$ within the same dependent variable, this poses no real threat to the conclusions. Furthermore, the percentages of correctly classified cases are provided as another method for comparing the results between models with and without values.

A limitation of the current study is that many of the values were deemed important by the respondents. As explained in the Introduction section, we had purposefully included housing-specific values in order to obtain a high relationship with residential preferences and choices. By applying a seven-point scale, we had expected to obtain sufficient variance in the responses in order to perform the analyses. However, the frequency distributions 
turned out to be highly skewed to the left. Such a finding is relatively common for values obtained using the method developed by Schwartz (1992). In his 1992 paper, Schwartz drops respondents from the analyses if they used the answering category "7" more than 21 times (of 56 values: $37 \%$ ) or used any other response more than 35 times. Schwartz argues that such respondents fail to make a serious effort to differentiate among their values. This approach was not followed in the current paper because of the belief that respondents who find many values important should be taken seriously. Another solution would have been to average-center the scores; this means removing, for every respondent, their grand mean from all individual scores to produce relative scores for analyses (in line with Schwartz 1992 , 2006). This procedure is specifically used by Schwartz $(1992,2006)$ to compare values between different countries. This approach was also not followed in the current paper because we did not want to predict residential preferences and choices on the basis of relative (within-person) differences in importance. Furthermore, this procedure would probably lead to the exaggeration of small differences in importance. Another drawback of the tendency to find many values important is that it might lead to high correlations between the values and, thus, to multicollinearity in the logistic regression analyses. A statistical analysis of correlations between the values showed that the highest correlation that was found between a pair of values was 0.42 for the relationship between "pleasure" and "enjoying life" (phi 4-point correlation for dichotomous variables). Thus, multicollinearity seems not to pose problems in the current study.

A final remark concerns the operationalization of lifestyle in the form of values. Another approach, using other latent variables, behavioral variables or a combination of latent and behavioral variables, could have produced stronger relationships with residential preferences and choices. More research is needed in order to find those behavioral or latent variables that really improve the prediction of the quantitative and qualitative housing demand. The current study shows that socio-demographic characteristics can still explain residential preferences and choices. Nevertheless, the recent shift on the housing market from a supplier-market to a market that is more focused on demand increases the importance of obtaining more precise insight into consumers' preferences (van der Wouden and Kullberg 2002). Furthermore, as van Diepen and Arnoldus (2003) argue, research into the potential determinants of residential preferences, such as attitude, opinions and values, can be used to guide housing policy. Lifestyle research might provide valuable insight into the relationships between residents and the choices that they make with regard to their residential environment.

Open Access This article is distributed under the terms of the Creative Commons Attribution License which permits any use, distribution, and reproduction in any medium, provided the original author(s) and the source are credited.

\section{References}

Anderson, W. T., \& Golden, L. L. (1984). Lifestyle and psychographics-A critical-review and recommendation. Advances in Consumer Research, 11, 405-411.

Bastiaansen, I. (1997). Leefstijlen als basis voor het nieuwe wonen. In J. Broess \& C. Grijzen (Eds.), Brabant ongemonteerd (pp. 5-20). Den Bosch: Projectburo Brabant 2050.

Bell, W. (1958). Social choice, life styles and suburban residence. In W. F. Dobriner (Ed.), The suburban community. New York: Putnam Books.

Bell, W. (1968). The city, the suburb and a theory of social choice. In S. Greer (Ed.), The new urbanization (pp. 132-168). New York: Putnam Books. 
Bootsma, H. G. (1995). The influence of a work-oriented lifestyle on residential location choice of couples. Journal of Housing and the Built Environment, 10(1), 45-63.

Bourdieu, P. (1984). Distinction. Cambridge: Harvard University Press.

Clark, W. A. V., Deurloo, M. C., \& Dieleman, F. M. (1994). Tenure changes in the context of microlevel family and macrolevel economic shifts. Urban Studies, 31(1), 137-154.

Clarke, D. B. (2003). The consumer society and the postmodern city. London: Routledge.

Coolen, H., Boelhouwer, P., \& van Driel, K. (2002). Values and goals as determinants of intended tenure choice. Journal of Housing and the Built Environment, 17, 215-236.

Coolen, H., \& Hoekstra, J. (2001). Values as determinants of preferences for housing attributes. Journal of Housing and the Built Environment, 16, 285-306.

de Wijs-Mulkens, E. (1999). Wonen op Stand. Lifestyles en Landschappen van de Culturele en Economische elite. Amsterdam: het Spinhuis.

de Wijs-Mulkens, E., \& Ostendorf, W. (2001). De smaak van het WBO. Smaak in twee dimensies. Tijdschrift voor de Volkshuisvesting, 8, 45-50.

Driessen, F. M. H. M., \& Beereboom, H. J. A. (1983). De kwaliteit van het stedelijk leefmilieu: Bewoners en hun voorkeuren. Utrecht: Rijksuniversiteit Utrecht, Vakgroep Theorie en Methodologie van de Sociologie.

Field, A. (2009). Discovering statistics using SPSS. Los Angeles: Sage.

Gans, H. (1968). Urbanism and suburbanism as ways of life. In R. Pahl (Ed.), Readings in urban sociology (pp. 95-114). London: Pergamon.

Ganzeboom, H. (1988). Leefstijlen in Nederland. Een verkennende studie. Sociaal en Cultureel Planbureau. Cahier no. 60. Alphen aan den Rijn: Samson Uitgeverij.

Ganzeboom, H. (1990). Leefstijlen: een theoretische en methodologische beschouwing met een empirisch voorbeeld. In Jaarboek van de Nederlandse Vereniging van Marktonderzoekers '89-90. Haarlem: De Vrieseborch.

Gunter, B., \& Furnham, A. (1992). Consumer profiles. An introduction to psychographics. London: Routledge.

Haest, G. (1989). De oude garde, het andere slag en de buitenlanders. Assen, Van Gorcum: De geschiedenis van een saneringswijk.

Hagen, G. J. (2001). Motivational profiling. De woonconsument als mens. Tijdschrift voor de Volkshuisvesting, 3, 6-11.

Hagen, G. J. (2006). Leefstijlen. De klant in de mand... Boss Magazine, April 22-27.

Heijs, W., Carton, M., Smeets, J., \& van Gemert, A. (2005). Labyrinth van leefstijlen. Eindhoven: Cahier Architectuur Stedebouw Eindhoven.

Heijs, W., Carton, M., Smeets, J., \& van Gemert, A. (2009). The labyrinth of life-styles. Journal of Housing and the Built Environment, 24(3), 347-356.

Heijs, W., van Deursen, A. M., Leussink, M., \& Smeets, J. (2011). Re-searching the labyrinth of life-styles. Journal of Housing and the Built Environment, 26, 411-425.

Hessing, E., \& Reuling, A. M. H. (2003). Waarden in Nederland. Segmentatie van doelgroepen. In A. E. Bronner, P. Dekker, J. C. Hoekstra, E. de Leeuw, T. Poiesz, K. de Ruyter, \& A. Smidts (Eds.), Ontwikkelingen in het Marktonderzoek: Jaarboek MarktOnderzoeksAssociatie (pp. 163-175). Haarlem: Spaar en Hout.

Hustad, P., \& Pessemier, E. (1974). The development and application of psychographic life-style and associated activity and attitude measures. In W. Wells (Ed.), Life-style and psychographics (pp. 32-70). Chicago: American Marketing Association.

Jansen, S. J. T. (2011). The lifestyle method. In S. J. T. Jansen, H. C. C. H. Coolen, \& R. W. Goetgeluk (Eds.), The measurement and analysis of housing preference and choice (pp. 177-202). Dordrecht: Springer.

Kahle, L. R. (1983). Social values and social change: adaptation to life in America. New York: Praeger.

Kersloot, J., \& Kauko, T. (2004). Measurement of housing preferences-A comparison of research activity in the Netherlands and Finland. Nordic Journal of Surveying and Real Estate Research, 1, 144-163.

Kipnis, B. A. (2004). Lifestyle studies-an editorial introduction. Geography Research Forum, 24, 1-20.

Kolpron Consultants and MarketResponse. (2000). Rapport Woonbeleving 2000. Amersfoort: The SmartAgent Company.

Lastovicka, J. L., Murry, J. P., \& Joachimstaler, E. A. (1990). Evaluating the measurement validity of lifestyle typologies with qualitative measures and multiplicative factoring. Journal of Marketing Research, 17, 11-23.

Lindberg, E., Gärling, T., \& Montgomery, H. (1988). People's beliefs and values as determinants of housing preferences and simulated choices. Scandinavian Housing \& Planning Research, 5, 181-197. 
Lindberg, E., Gärling, T., \& Montgomery, H. (1989). Belief-value structures as determinants of consumerbehavior-A study of housing preferences and choices. Journal of Consumer Policy, 12, 119-137.

Lindberg, E., Hartig, T., Garvill, J., \& Gärling, T. (1992). Residential-location preferences across the life span. Journal of Environmental Psychology, 12, 187-198.

Lundgren, B. A., \& Lic, T. (2010). Customer perspectives on a residential development using the laddering method. Journal of Housing and the Built Environment, 25(1), 37-52.

Merton, R. K. (1957). Social theory and social structure. Glencoe, IL: Free Press.

Michelson, W., \& Reed, P. (1974). Lifestyle in environmental research. In C. Beattie \& S. Crysdale (Eds.), Sociology Canada: Readings (pp. 406-419). Toronto: Butterworths.

Nijhuis, M., \& Schoemaker, R. (2002). Normen, waarden en woonbelevingsgroepen. Consumentenonderzoek van Motivaction. Stedebouw en Ruimtelijke Ordening, 6, 43-45.

Nio, I. (2002). Van levenswijzen tot lifestyles. Over de bruikbaarheid van leefstijlen voor de ruimtelijke ordening. Stedebouw \& Ruimtelijke Ordening, 6, 6-10.

Overboom, L.(2003). Tussen klant en stad. Cahier reeks Duurzame stedelijke vernieuwing (2(11)). KEI Kenniscentrum Stedelijke Vernieuwing en NIDO Programma Duurzame Stedelijke Vernieuwing.

Pinkster, F., \& van Kempen, R. (2002). Leefstijlen en Woonmilieuvoorkeuren. Utrecht: University of Utrecht, Urban and Regional Research Centre.

Prensky, D., \& Wright-Isak, C. (1997). Advertising, values and the consumption community. In L. R. Kahle \& L. Chiagouris (Eds.), Values, lifestyles and psychographics (pp. 69-81). Mahwah, NJ: Lawrence Erlbaum Associates, Publishers.

Reijndorp, A., Kompier, V., Metaal, S., Nio, I., \& Truijens, B. (1998). Buitenwijk. Stedelijkheid op afstand. Rotterdam: NAi Uitgevers.

Rokeach, M. (1973). The nature of human values. New York: Free Press.

Schwartz, S. H. (1992). Universals in the content and structure of values: theoretical advances and empirical tests in 20 countries. In M. P. Zanna (Ed.), Advances in experimental social psychology (Vol. 25, pp. 1-65). San Diego: Academic Press.

Schwartz, S. H. (2006). A theory of cultural value orientations: Explication and applications. Comparative Sociology, 5(2-3), 137-182.

Schwartz, S. H., \& Boehnke, K. (2004). Evaluating the structure of human values with confirmatory factor analysis. Journal of Research in Personality, 38, 230-255.

Sobel, M. (1981). Lifestyle and social structure: Concepts, definitions, analysis. New York: Academic Press.

Tallman, I., \& Morgner, R. (1970). Life-style differences among urban and suburban blue-collar families. Social Forces, 48(3), 334-348.

The SmartAgent Company. (2005). De grote woontest 2004. Feiten en beleving van het wonen in de regio Rotterdam. Rotterdam: The SmartAgent Company.

Urhahn Urban Design. (1999). Suburbaan wonen in de stad. Een onderzoek naar de kwaliteit en duurzaamheid van woonmilieus in Apeldoorn.

van der Schaaf, R. (2002). Leefstijlen en woonmilieus in de wijkvernieuwing. De Groninger methode. Stedebouw \& Ruimtelijke Ordening, 6, 40-42.

van der Wouden, R., \& Kullberg, J. (2002). Stijloefeningen. Leefstijlen in onderzoek en praktijk. Stedebouw \& Ruimtelijke Ordening, 6, 13-20.

van Diepen, A. M. L., \& Arnoldus, M. (2003). De woonvraag in de vraaggestuurde markt. Bouwstenen uit het woonmilieuanalyse en leefstijlenonderzoek (rapport 23). Utrecht: DGW/Nethur partnership.

van Diepen, A., \& Musterd, S. (2001). Stedelijke leefstijlen en woonmilieus in Amsterdam. Amsterdam: Amsterdam study centre for the Metropolitan Environment.

van Diepen, A. M. L., \& Musterd, S. (2009). Lifestyles and the city. Housing and the Built Environment, 24, 331-345.

van Engelsdorp-Gastelaars, R. (1980). Niet elke stadsbewoner is een stedeling. Amsterdam: Universiteit van Amsterdam, Sociaal-Geografisch Instituut.

Vyncke, P. (2002). Lifestyle segmentation: From attitudes, interests and opinions, to values, aesthetic styles, life visions and media preferences. European Journal of Communication, 17, 445-463.

Wedel, M., \& Kamakura, W. A. (2000). Market segmentation: Conceptual and methodological foundations (2nd ed.). Norwell: Kluwer Academic Publishers.

Wells, W. (Ed.). (1974). Life-style and psychographics. Chicago: American Marketing Association.

Wirth, L. (1938). Urbanism as a way of life. The American Journal of Sociology, 44(1), 1-24.

Zablocki, B. D., \& Kanter, R. M. (1976). Differentiation of life-styles. Annual Review of Sociology, 2, 269-298.

Zukin, S. (1998). Urban lifestyles: Diversity and standardisation in spaces of consumption. Urban Studies, $35,825-839$. 